$-196^{\circ} \mathrm{C}$. More carbon dioxide evolved the first day from soil frozen prior to incubation than from soil not frozen and the difference decreases with successive incubation cycles. However, the total amount of carbon dioxide evolved from the frozen sample was nearly the same as that from the unfrozen one. A detailed study of the results not presented shows that after the first few days of each incubation period, the rate of evolution between the frozen and unfrozen samples was similar for the remainder of the incubation period.

To show effects of freezing a warm soil $\left(24^{\circ} \mathrm{C}\right.$.) and a chilled soil $\left(-1^{\circ} \mathrm{C}\right.$.), the amount of $\mathrm{NO}_{3}$, bacterial and fungal counts, and plant yields are presented in Table 3 for four of the treatments previously described; (a) $24^{\circ} \mathrm{C}$., (b) $24^{\circ} \mathrm{C}$. followed by freezing at $-196^{\circ}$ C., $(c)-1^{\circ}$ C., $(d)-1^{\circ}$ C. followed by freezing at $-196^{\circ} \mathrm{C}$. The amount of $\mathrm{NO}_{3}-\mathrm{N}$ and the yield of plant material were higher for the soils which had been frozen at $-196^{\circ} \mathrm{C}$. than for the two soils which had not been so frozen. The number of fungi was reduced greatly in the soil which had been frozen at $-196^{\circ} \mathrm{C}$. and especially so in the sample which had been at $24^{\circ} \mathrm{C}$. prior to freezing. Chilling the soil to $-1^{\circ} \mathrm{C}$. for 4 days prior to freezing at - $196^{\circ} \mathrm{C}$. appeared to increase the resistance of the fungi to the effects of low-temperature freezing.

In conclusion, the results show that the amount of nitrogen transformed to $\mathrm{NO}_{3}-\mathrm{N}$ on incubation is strikingly increased in soil which has been previously frozen to a low temperature. It is suggested that freezing affects the organic matter which in turn affects the nutrient supply for the microorganisms.

I acknowledge the assistance of Dr. K. C. Ivarson.

Soil Research Institute,

Research Branch,

Canada Department of Agriculture, Ottawa.

4 Mack, A. R., and Barber, S. A., Soil Sci. Soc. Amer. Proc.,24, 381 (1960).

\section{Resin Impregnation of Soil Samples}

THrN sections of clay soils containing finely divided calcite could not be made satisfactorily unless completely impregnated with resin. The resins most successfully used were 'Marco Resin $S B$ 28C' (an unsaturated polyester resin supplied by Scott Bader and Co., Ltd., Wollaston, Wellingborough, Northants.) and 'Araldite $M Y 750$ ' (an epoxy resin supplied by C.I.B.A. (ARL), Ltd., Duxford, Cambridge) (Table 1). They are both isotropic, have convenient refractive indices ('Marco', 1.55-1.56; 'Araldite', 1.54-1.55), low viscosities and, being thermo-setting, allow long soaking times to be used.

Table 1. Recipes for Resin Mtxtures

$\begin{array}{lcc} & \text { Parts by weight } \\ 1 \text { 'Marco Resin } S B 28 C^{*} & 100 \\ \text { Monomer } C \text { (modified 'Styrene') } & 40 \\ \text { Catalyst paste } B & 1 \\ 2 \text { 'Araldite } M Y 750 \text { ' } & 100 \\ \text { Hardener } H Y 905 & 100 \\ \text { Plasticiser } D Y 001 & 0.5\end{array}$

Preliminary trials established that long soaking times improve impregnation, but do not compensate for poor initial entry of resin, that is, at the stage when the viscosity is lowest. For rapid and deop penetration, imprognation in vacuo is proferable to pouring resin over the sample and then evacuating. The vacuum should be released within $10-15 \mathrm{~min}$. of the sample being covered; without exception, if it was held beyond this time impregnation was less and less penetrating. The degree of vacuum after the sample has been covered must be limited to a level that will not favour bubbles of vapours being formed and trapped inside it. For the 'Marco Resin' mixture a critical value is about $250 \mathrm{~mm}$. pressure, but it is considerably less for 'Araldite' ('Hardener HY 905' and 'Styrene' have vapour pressures of $1 \mathrm{~mm}$. at $105^{\circ} \mathrm{C}$. and $-7^{\circ} \mathrm{C}$. respectively).

The technique aims at avoiding contact between the resin and substances like grease or rubber that delay or inhibit its setting, to remove as much water as possible, to encourage uninhibited access for the resin into the smaller pores, and to allow time for its further penetration by capillarity.

Samples are dried at $105^{\circ} \mathrm{C}$. and put under vacuum $(0.05 \mathrm{~mm}$. pressure) while still hot. The resin mixture is evacuated separately under the moderate vacuurn of a water pump (12 $\mathrm{mm}$. pressure) before being admitted in vacuo into the sample container (Fig. 1). (Lead containers, supplied by Betts and Co., Ltd., Elthorne Road, London, N.19, were used for impregnations with 'Araldite'.) As soon as the sample has been covered the vacuum is reloased. It is allowed to soak for several days and can be made to set at any time by heating the 'Marco Resin' to about $80^{\circ} \mathrm{C}$. and the 'Araldite' to about $120^{\circ} \mathrm{C}$. 'To take advantage of the steep fall in viscosity of 'Araldite' at higher temperatures, as much of the process as possible from resin mixing onwards is kept at $80^{\circ}$ C., but 'Marco' impregnations are done at room temperature.

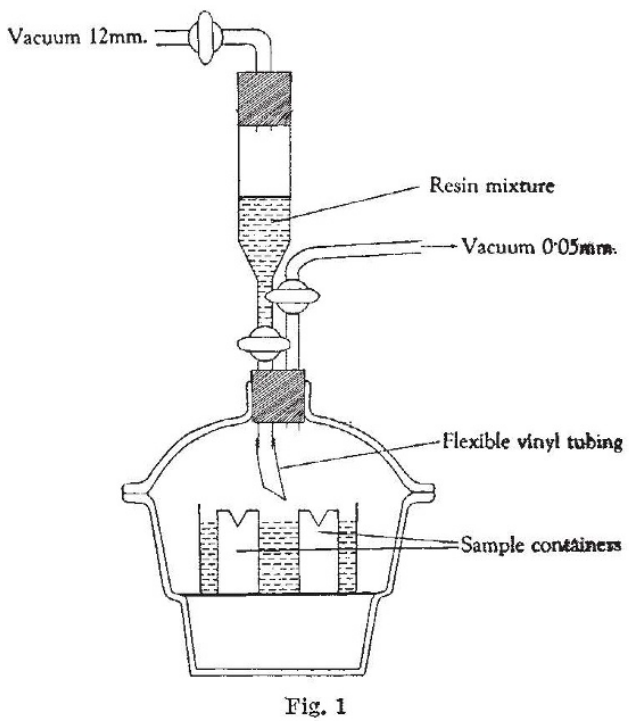

For many samples both resins appear equally satisfactory, but 'Araldite' proved superior for the very fine-textured soils and for samples containing organic matter. The choice depends partly on convenience, refractive index and the necessity or otherwise to uso glass containers.

Details of the method will be available later from the Commonwealth Scientific and Industrial Research Organization, Division of Soils, Adelaide, South Australia.

Pedology Departmont,

C. B. Wents

Rothamsted Experimental Station, Harpenden. 